\title{
The Banded Elm Bark Beetle, Scolytus schevyrewi Semenov (Coleoptera, Curculionidae, Scolytinae) in North America: a taxonomic review and modifications to the Wood (1982) key to the species of Scolytus Geoffroy in North and Central America
}

\author{
James R. LaBonte \\ Plant Division, Oregon Department of Agriculture, 635 Capitol Street, Salem, Oregon, 97301-2532, U.S.A. \\ Corresponding author:James R. LaBonte (jlabonte@oda.state.or.us) \\ Academic editor: R. Hoebeke| Received 10 November 2009 | Accepted 25 January 2010 | Published 17 September 2010 \\ Citation: LaBonte JR (2010) The Banded Elm Bark Beetle, Scolytus scheryrewi Semenov (Coleoptera, Curculionidae, \\ Scolytinae) in North America: a taxonomic review and modifications to the Wood (1982) key to the species of Scolytus \\ Geoffroy in North and Central America. In: Cognato AI, Knížek M (Eds) Sixty years of discovering scolytine and \\ platypodine diversity: A tribute to Stephen L. Wood. ZooKeys 56: 207-218. doi: 10.3897/zookeys.56.527
}

\begin{abstract}
In 2003, an Asian bark beetle, Scolytus schevyrewi Semenov (Coleoptera: Curculionidae: Scolytinae), the banded elm bark beetle, was detected for the first time in North America. This paper modifies the Wood (1982) key to the species of Scolytus Geoffroy to enable identification of S. scheryrewi in North and Central America. Variation of diagnostic characters in S. schevyrewi is discussed.
\end{abstract}

\section{Keywords}

Scolytus schevyrewi, banded elm bark beetle, exotic species, Scolytinae

\section{Introduction}

A growing number of exotic wood boring or wood associated beetles have recently been found to be established in North America (e.g., Hoebeke 1994; Hoebeke 1999; Maier and Lemmon 2000; Vandenberg et al. 2000; Mudge et al. 2001; CFIA 2002; McCullough and Roberts 2002; LaBonte et al. 2005; Haack 2006; Lee et al. 2008). In response to this trend, a multiagency pilot project to detect exotic Scolytinae throughout

Copyright James R. LaBonte. This is an open access article distributed under the terms of the Creative Commons Attribution License, which permits unrestricted use, distribution, and reproduction in any medium, provided the original author and source are credited. 
the United States was initiated in 2001. This program was initially designated the Exotic Forest Pest Early Detection and Rapid Response Program, but is now known as the Early Detection and Rapid Response program, or EDRR (Rabaglia et al. 2008). Since 2007, the EDRR program has been implemented on a national level under the auspices of the USDA Forest Service and, as of 2009, most states in the U.S. have been particpants.

As the cooperating taxonomist for the western states participating in the 2003 EDRR program, specimens from Lindgren funnel traps used in this survey were sent to me for identification. Early samples from the Denver, Colorado, metropolitan area contained several specimens of a species of Scolytus Geoffroy unfamiliar to me and that I was unable to key to any species in Wood (1982). I consequently sent specimens to Dr. Stephen L. Wood (deceased), Dr. Donald E. Bright (emeritus, Colorado State University, Fort Collins, Colorado) and Dr. Natalia J. Vandenberg (U.S.D.A., Agricultural Research Service, Systematic Entomology Lab, Washington, DC). These taxonomic authorities determined the specimens to be Scolytus schevyrewi Semenov, an Asian species previously unknown from North America. Shortly thereafter, I found specimens of S. schevyrewi in samples from Ogden, Utah.

Subsequent trapping found this species to be abundant and clearly established in Denver and Ogden. These data stimulated extensive trapping surveys throughout Colorado and Utah, where it was found at most sites. The realization that $S$. schevyrewi was widely distributed in Colorado and Utah prompted several neighboring states to initiate surveys as well. At the end of 2003, S. schevyrewi had been detected in twelve additional states (Negron et al. 2005). By 2008, this supposedly new exotic species had been found from coast to coast in twenty-eight states (with the earliest records from 1994), as well as in southern Canada (Lee et al. 2009). As yet, there are no records of S. schevyrewi from Mexico.

\section{Methods}

Existing taxonomic treatments for North American Scolyus (Bright 1975; Wood 1982; Furniss and Johnson 2002) do not include S. schevyrewi as it was unknown from this continent when those were published. Shortly after the detection of $S$. schevyrewi in Colorado and Utah, an image-based aid to the identification of this species was placed on the Purdue University NAPIS (National Agricultural Pest Information Site) website (LaBonte et al. 2003). This aid is more streamlined than the following modifications to the Wood (1982) key and emphasizes the differences between S. schevyrewi and S. multistriatus (Marsham) because the latter is much more apt to be encountered in surveys than is $S$. piceae (Swaine). However, this early treatment is incomplete as it does not include some diagnostic characters subsequently found nor was the range of variation of some characters recognized.

The diagnostic characters used to differentiate $S$. schevyrewi from other species of Scolytus are mainly based on specimens acquired via the EDRR project and a variety of wood boring insect surveillance programs, most funded via the USDA Cooperative Agricultural Pest Survey (CAPS) program. I have examined over 7,600 specimens of $S$. schevyrewi from these surveys. 


\section{Distinguishing Scolytus schevyrewi from other species of Scolytus in North and Central America}

The following modifications to Wood's (1982) key to the species of Scolytus in North and Central America will serve to identify typical specimens of $S$. schevyrewi. Very little of the text in his key remains in the couplets below, other than the distributions, hosts, and size ranges for species dealt with therein. Several characters used in his key to discriminate among these species are not used because they are unnecessary or lead to an unduly cumbersome key, are too variable, or cannot be accurately assessed without reliably identified reference specimens, a resource many users of this key will lack. These characters can include the relative sizes of interstrial and strial punctures, whether the elytral interstriae are impressed, and subtle differences in size among abdominal sternal punctures.

8(7). Sternum 2 with base of spine touching its anterior margin (Fig. 1); posterolateral margins of sterna $2-4$ each bearing small, distinct, sharply pointed tubercles (those on sternum 4 often obscured by elytra) (Fig. 2); median posterior margin of sternum 1 convex (Fig. 3); elytra unicolorous brown (Fig. 4); British Columbia and Nova Scotia to California and Florida to California and Florida; Ulmus; 1.9-3.1 mm (dorsal habitus Fig. 4, lateral habitus Fig. 5) ....

multistriatus (Marsham)
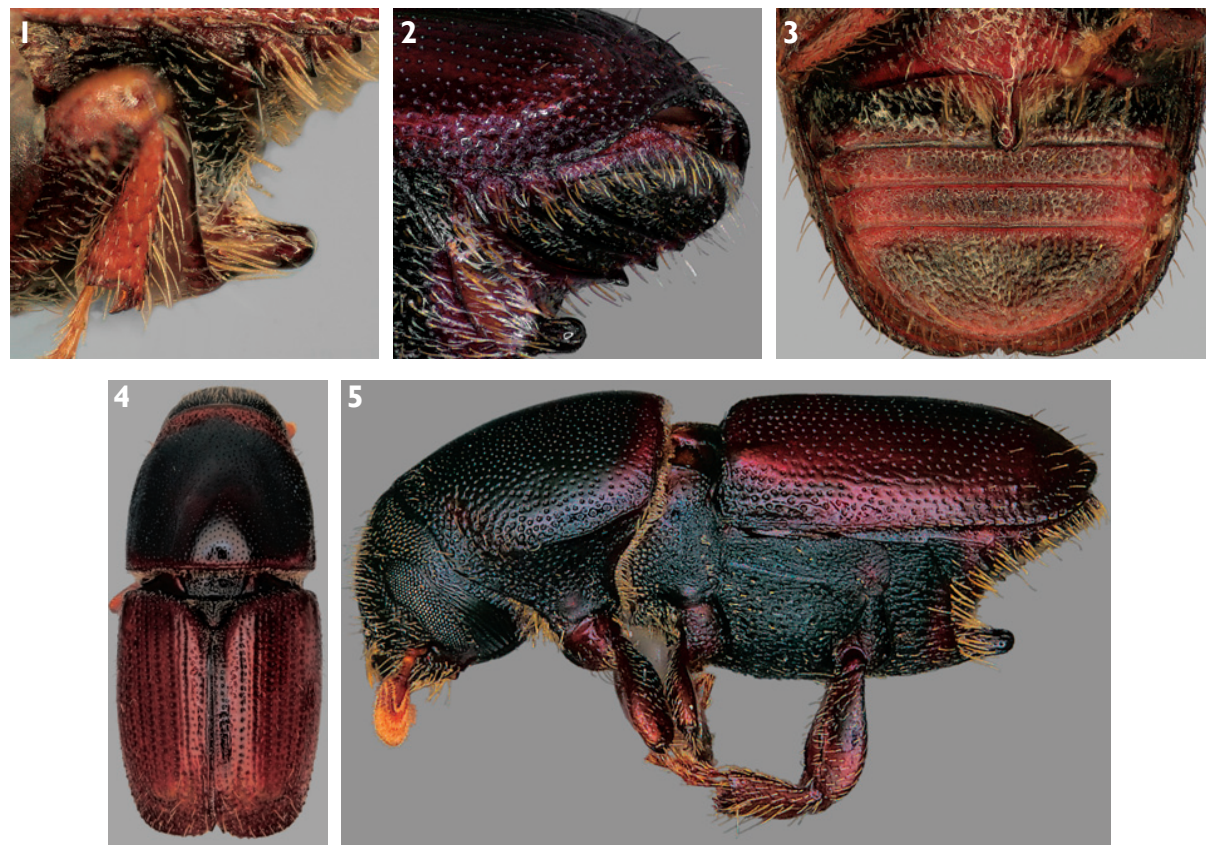

Fugires I-5. I Lateral view of spine on abdominal sternum 2 of Scolytus multistriatus $\mathbf{2}$ Lateral view of abdominal sterna of Scolytus multistriatus, showing lateral tubercles $\mathbf{3}$ Ventral view of abdominal sterna of Scolytus multistriatus 4 Dorsal habitus of Scolytus multistriatus 5 Lateral habitus of Scolytus multistriatus. 
- $\quad$ Sternum 2 with base of spine remote from its anterior margin (Figs 6, 7); posterolateral margins of sterna 2-4 lacking tubercles (Figs 6, 8); median posterior margin of sternum 1 convex (Fig. 9) or concavely truncate (Fig. 10); in coniferous or deciduous hosts
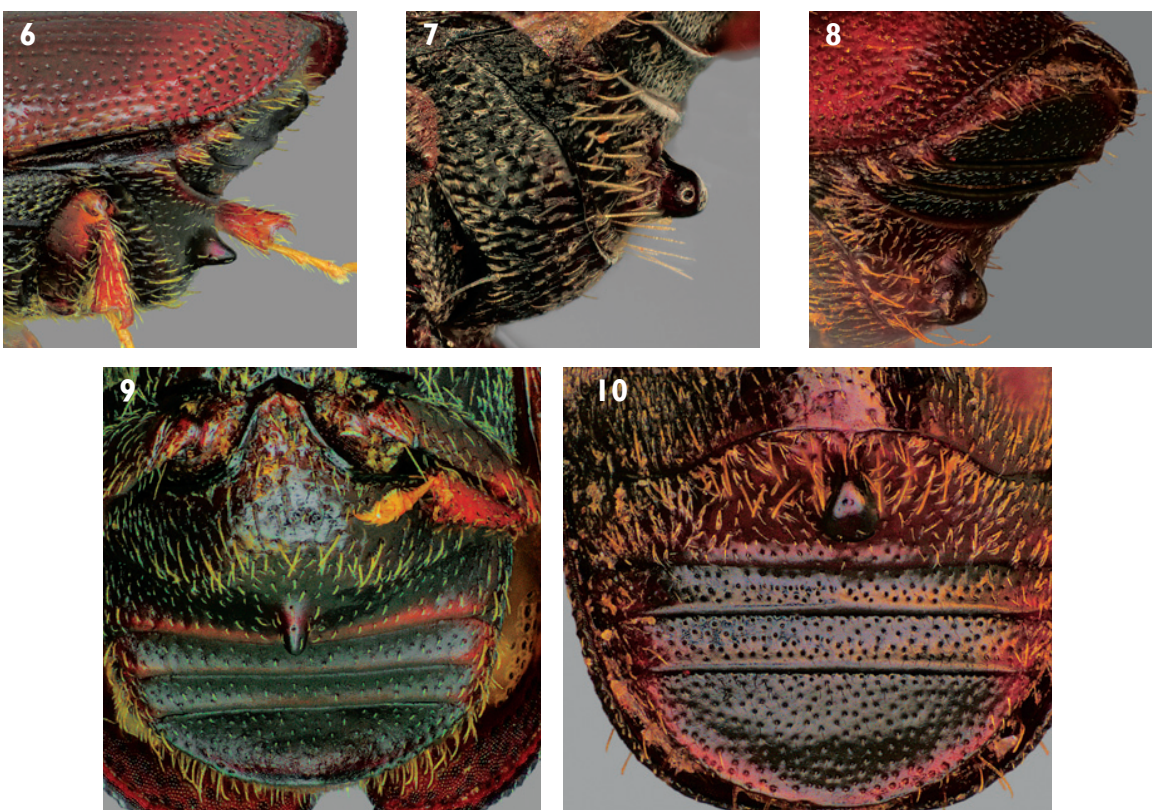

Fugires 6-10.6 Lateral view of abdominal sterna of Scolytus piceae 7 Lateral view of abdominal sterna of Scolytus schevyrewi 8 Oblique lateral view of abdominal sterna of Scolytus schevyrewi $\mathbf{9}$ Ventral view of abdominal sterna of Scolytus piceae 10 Ventral view of abdominal sterna of Scolytus schevyrewi.

9(8). Spine on sternum 2 with base remote from posterior margin of segment (Figs 6, 7) .........................................................................9a

- $\quad$ Spine on sternum 2 in contact with posterior margin of segment (Figs 11, 12). 10
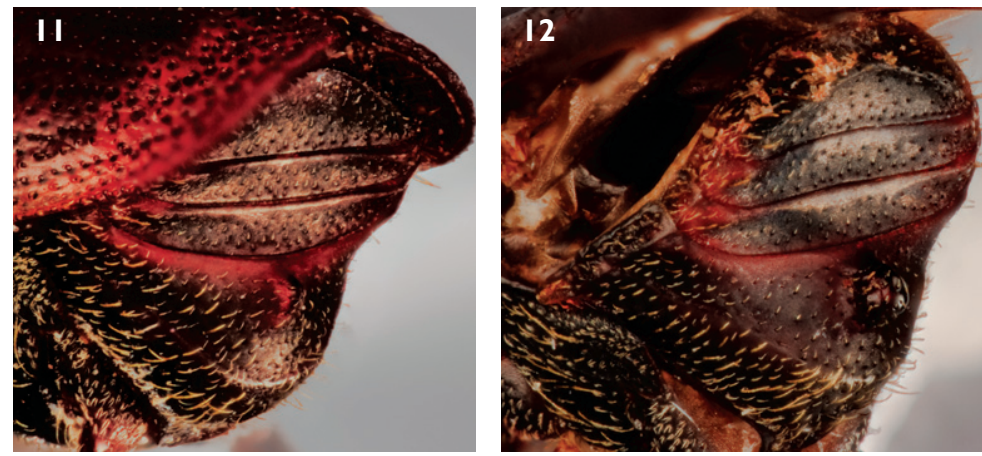

Fugires II-I2. II Oblique lateral view of abdominal sterna of female Scolytus unispinosus LeConte 12 Oblique lateral view of abdominal sterna of male Scolytus unispinosus LeConte. 
9a. Spine on sternum 2 narrowly conical and sometimes pointed at apex in lateral (Fig. 6), ventral (Fig. 9), and apical (Fig. 13) views; median posterior margin of sternum 1 convex (Fig. 9); last abdominal sternum with transverse carinae distant from apex (Fig. 13); elytra unicolorous brown (Figs 14, 15); interstriae not impressed and diameter of interstrial punctures less than those of striae (Fig. 14); pronotum dark with at most very narrow pale banding along anterior and posterior margins (Fig. 15); Alaska and Nova Scotia to California and New York; Picea and, rarely, Larix; 2.2-2.8 mm (dorsal habitus Fig. 15, lateral habitus Fig. 16) 7. piceae (Swaine)
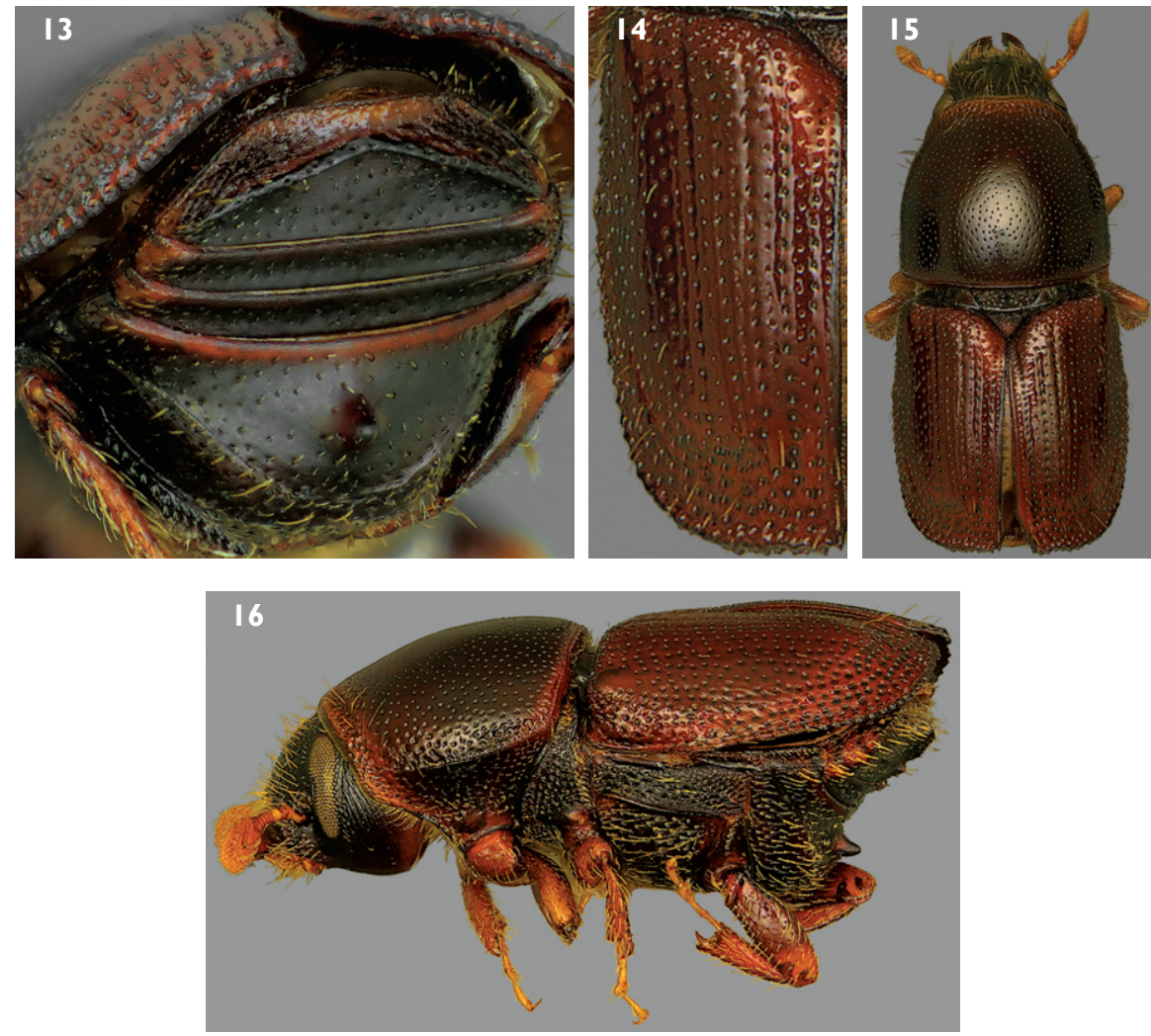

Fugires I3-16. 16 Posterior view of abdominal sterna of Scolytus piceae I4 Dorsal view of left elytron of Scolytus piceae 15 Dorsal habitus of Scolytus piceae 16 Lateral habitus of Scolytus piceae.

- $\quad$ Spine on sternum 2 variable, from almost absent to strongly developed, but most often broadly conical and blunt at apex in lateral view (Figs 17-20), apex often broader than base in ventral view (Fig. 10) and flattened in apical view (Fig. 21); occasional aberrant specimens with a spine on sternum 2 and a second spine on sternum 3 (Figs 22, 23); median posterior margin of sternum 1 emarginate or truncate (Fig. 10); last abdominal sternum with transverse carina very near apex (Fig. 21); elytra almost always with dark median band, with bases and apices pale (Figs 24, 25) although this band may 
be indistinct (Fig. 26); interstriae often impressed and diameter of interstrial punctures subequal to those of striae (Fig. 27); pronotum generally with relatively extensive pale coloration (Figs 24-26); currently known from most of the coterminous states in the U.S.A. (except for the southeastern states) and from southern Canada; deciduous hosts (known only from Ulmus in North America); 2.7-4.3 mm (dorsal habitus Figs 24-26, lateral habitus Fig. 28) (not in Wood 1982). schevyrewi Semenov
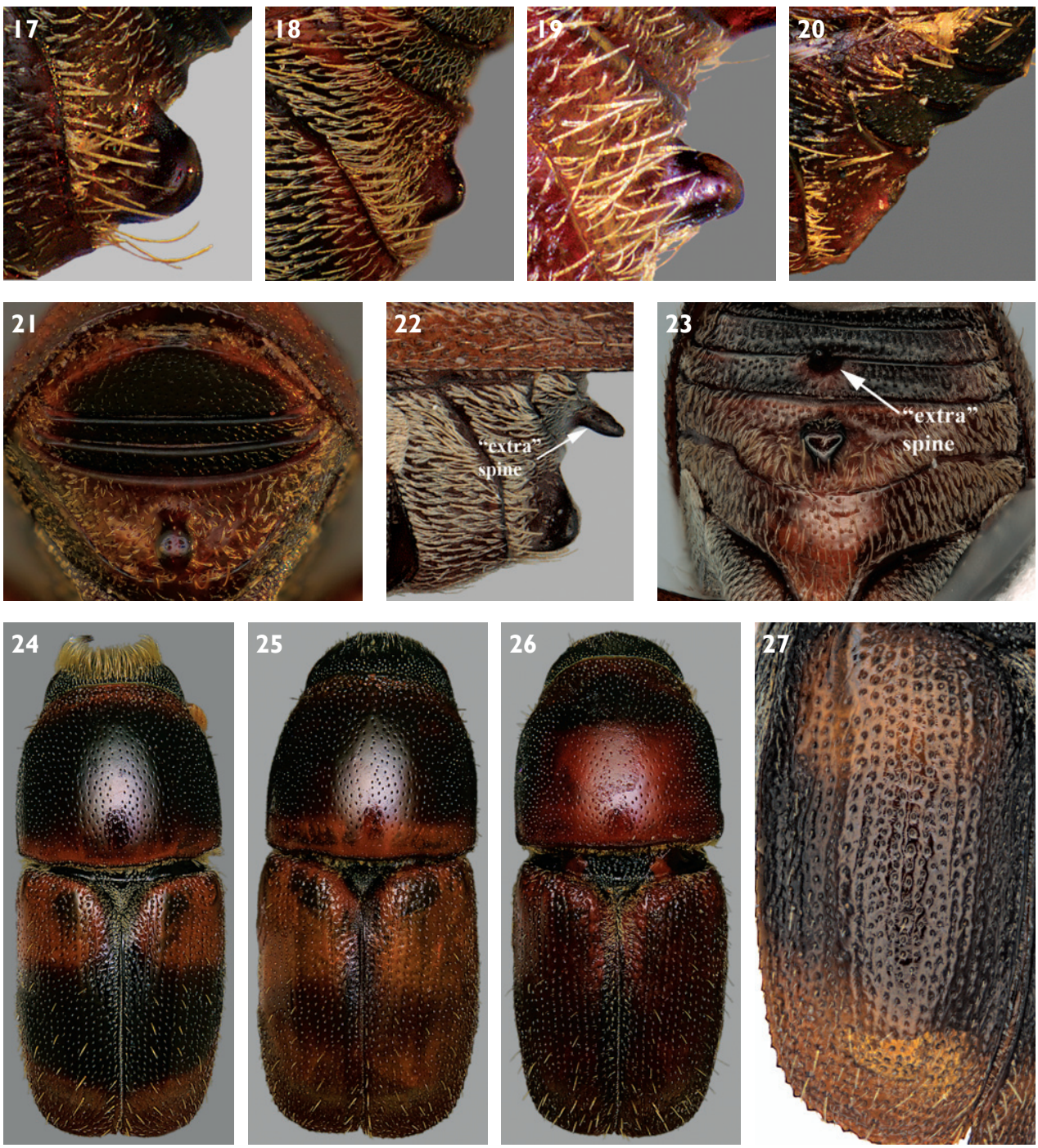

Figures 17-27. 17-20 Variation in spine on abdominal sternum 2 of Scolytus schevyrewi 21 Posterior view of abdominal sterna of Scolytus schevyrewi 22 Lateral view of abdominal sterna of Scolytus schevyrewi with two abdominal spines $\mathbf{2 3}$ Posterior view of abdominal sterna of Scolytus schevyrewi with two abdominal spines 24-26 Dorsal habitus and variation in elytral and pronotal coloration of Scolytus schevyrewi 27 Dorsal view of left elytron of Scolytus schevyrewi. 


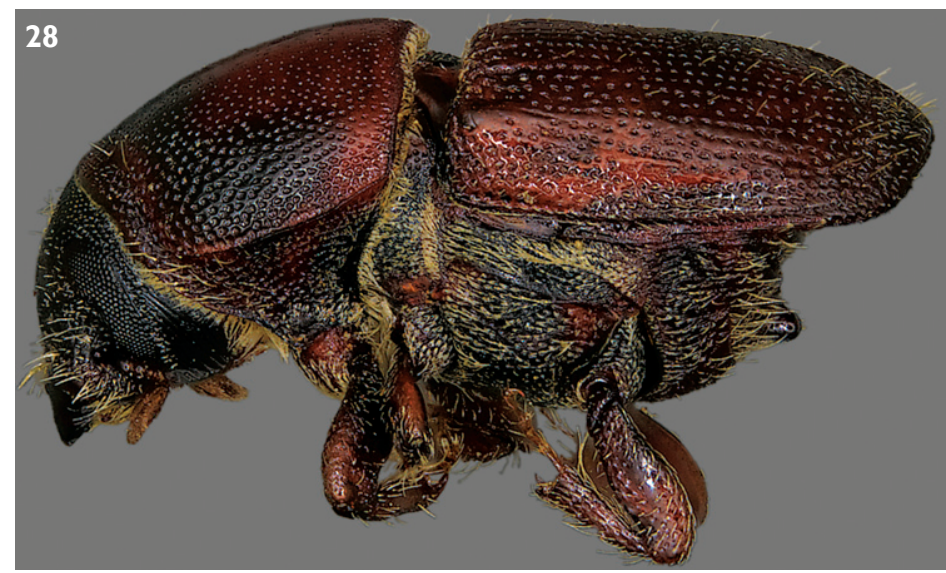

Fugire 28. Lateral habitus of Scolytus schevyrewi.

\section{Diagnostic summary and character variation}

Typical specimens of $S$. schevyrewi cannot be easily confused with any other species of Scolytus known from North America. The shape and position of the spine on sternum 2 (Figs 7-8, 10, 17-21), especially in males, and typical coloration (Figs 24-26) are unique relative to all other North American species. However, this is a highly variable species and it is advisable to use a suite of characters for its identification. The following elaboration on variation in $S$. schevyrewi is based upon the examination of thousands of specimens of that species and of $S$. multistriatus, the species most apt to be confused with $S$. schevyrewi.

There can be great variation in the shape and position of the spine on sternum 2. Males most often have the spine well developed, with a blunt apex that is broader than the base, appearing triangular in ventral view (Fig. 10). Especially with females, this feature can be variously reduced, becoming almost absent in the most extreme cases (Fig. 20). Reduction of the spine can lead to possible confusion with specimens of $S$. multistriatus that have malformed or broken spines, which are not uncommon in large series thereof. However, as indicated previously, in S. schervyrewi, the base of the spine on sternum 2 is remote from the anterior margin, almost at the center, whereas in $S$. multistriatus the base of the spine is in contact with the anterior margin. Some $S$. schevyrewi, especially those with larger spines, can have the base of the spine positioned anterior of the center of sternum 2, compounding the possibility of confusion with aberrant $S$. multistriatus. Inadequately cleaned $S$. multistriatus may have debris under the base of the spine, which can make its lateral appearance broader than is the case. An extreme example of abdominal spine variation in $S$. schevyrewi is exhibited in a male from California (courtesy of R.L. Penrose, California Department of Food and Agriculture) (Figs 22, 23). In this instance, a second, accessory, sharply conical spine is present on the third abdominal sternum. This spine is asymmetrically positioned (Fig. 23), leading to my conclusion that this specimen represents a developmental aberra- 
tion rather than a different species. In all other respects, this specimen appears to be a typical S. schevyrewi.

The elytron of a normal $S$. schevyrewi is distinctively colored, with a variably developed median dark band and the base and apex distinctly pale (Figs 24, 25). This character enables rapid identification of this species as no other North American species has this color pattern. The dark median band is best observed in well dried specimens; it can be obscured in specimens still damp from collecting in liquid or storage in alcohol. However, there are occasional specimens with apparently unicolorous dark or pale elytra (Fig. 26). Some samples exhibited higher proportions of these unicolorous specimens, but probably less than 10\%. The existence of individuals with concolorous elytra dictates caution in complete reliance upon color for identification of S. schevyrewi, as both $S$. multistriatus and $S$. piceae normally have concolorous elytra. Some $S$. multistriatus also have elytra with dark apices and bases, with pale median areas.

The pronotum of a typically colored $S$. schevyrewi is also distinctively colored, with relatively extensive areas of pale coloration (Figs 24-26). The extent of the pale areas is highly variable. The most common pattern is a fairly broad pale band along the posterior margin with a somewhat narrower pale band along the anterior margin (Figs 24, 25). Many specimens have the pale coloration extending from the posterior margin into the median area (Fig. 26). This pale coloration can sometimes cover almost the entire dorsum of the pronotum. On the other hand, in some specimens the pronotum is essentially completely dark, with only hints of anterior and posterior pale marginal banding. The extent of pale pronotal coloration appears independent of the size and extent of the median dark elytral band and the darkness of the ground color of the elytra. Several of the specimens of $S$. multistriatus I've examined have large, nebulously paler areas in the median area of the pronotum. As with elytral coloration, pronotal coloration should be used with some caution to distinguish $S$. schevyrewi from $S$. multistriatus and $S$. piceae.

As indicated in the key, specimens of $S$. schevyrewi average larger than either $S$. multistriatus or S. piceae. However, small S. schevyrewi fall within the size range of both of the other species. Furthermore, large $S$. multistriatus approach the size of average or even large $S$. schevyrewi.

Specimens of $S$. multistriatus have distinct, pointed tubercles or "teeth" on the posterior lateral margins of sterna 2-4 (Fig. 2). Specimens of S. piceae and S. schevyrewi lack this feature (Figs 6,8). This character is occasionally obscured in specimens of S. multistriatus swollen with liquid preservatives, but it can normally be observed by examining the lateral margins of the sterna from an oblique perspective.

The posterior margin of sternum 2 is distinctly truncate or slightly emarginate in almost all S. schevyrewi examined (Fig. 10). On the other hand, in S. multistriatus (Fig. 3) and S. piceae (Fig. 9) the posterior margin of sternum 2 is normally slightly to pronouncedly convex and in $S$. multistriatus is often slightly produced at the base of the spine (Fig. 3).

The elytron of a $S$. schevyrewi specimen in good condition typically displays three rows of relatively stout, long, discal setae that are about twice as long as the width of 
the elytral intervals (Figs 24-26). The elytra of most $S$. multistriatus lack distinct rows of discal setae, although there are generally setae at the elytral apices and there may be discal setae (Fig. 4). If discal setae are present, they are generally scattered, are less stout than those of $S$. schevyrewi and are shorter, about as long as the width of the elytral intervals. Of the small series of $S$. piceae examined, most lacked discal setae (Fig. 14). A few specimens had a row of 3 or 4 discal setae on interval 7, but these setae were short and fine, similar to those of $S$. multistriatus.

On visble abdominal sterna $3-5$, the setae of $S$. schevyrewi are short and recumbant (Figs 8, 10). Those of $S$. piceae are even shorter, often difficult to discern, and are also recumbant (Figs 6,9). In contrast, specimens of $S$. multistriatus often have long, semierect setae on these sterna, especially on sternum 5 (Figs 2, 3).

In summary, a suite of characters is best used to reliably identify S. schevyrewi. Especiallly with regard to $S$. multistriatus, these include (more or less in order of reliability and ease of assessment) the shape and position of the spine on sternum 2, normal elytral and pronotal coloration, the absence of lateral teeth on sterna $2-4$, average size, the truncate or slightly emarginate posterior margin of sternum 2, relatively abundant and large discal elytral setae, and short, recumbant setae on sterna 3-5.

\section{Discussion}

The U.S. specimens collected prior to 2003, along with the extensive U.S. distribution of $S$. schevyrewi and its great abundance in many areas, provide ample evidence that this exotic species is not new to the U.S. but is instead a legacy species that has been present for decades. Such legacy species, e.g., Xyleborinus alni (Niisima) (Mudge et al. 2001; LaBonte et al. 2005; Hoebeke and Rabaglia 2007), are probably more often the norm for newly detected exotic wood boring insects than otherwise. This is a consequence of the current surveillance technology, the limited survey efforts of the past, and the limited taxonomic expertise available to deal with the many thousands of specimens generated by current surveys.

There are profound taxonomic challenges presented by the remaining pool of undetected legacy species, truly newly introduced exotics, and the onslaught of continued new introductions as a consequence of global trade. Almost all existing taxonomic works for scolytines in North America, let alone other taxa of wood boring or wood associated insects, quite reasonably treat only those species previously known from this continent. The taxonomic infrastructure available to support surveillance for a wide spectrum of exotic wood borers has been eroding for decades and may have declined below critical and self sustaining levels. New technologies, such as extended depth of field macroscopy and LUCID ${ }^{\mathrm{TM}}$ go far to bridge this taxonomic impediment, e.g., a recent guide to the North American Siricidae (Schiff et al. 2006). Nonetheless, exotic wood boring insects, such as $S$. s. schevyrewi, will continue to evade recognition and detection unless substantial funds and resources are devoted to expanding our taxonomic base. 


\section{Acknowledgements}

Stephen L. Wood identified the first EDRR specimens of S. s. schevyrewi. He was also very generous with his time with regard to identifications of other challenging scolytines. North American Scolytinae taxonomy would be unrecognizable without his contributions. I will sorely miss him.

Donald E. Bright, who has also contributed mightily to North American scolytine taxonomy, confirmed Dr. Wood's identification of the initial EDRR specimens of $S$. schevyrewi. I am very grateful to him for his generosity and taxonomic support. Natalia J. Vandenberg also confirmed Dr. Wood's initial identification.

My long-suffering friends and colleaagues, E. Richard Hoebeke and Robert J. Rabaglia, reviewed many versions of this manuscript and offered much valuable advice to improve it, as well as relentless prodding me to complete it. Several of my ODA colleagues, especially Joshua A. Vlach, provided valuable insights as well.

I am grateful to those USFS colleagues who invited me into the EDRR fold early on, especially Donald A. Duerr and Iral R. Ragenovich.

I could not have recognized the significant characters and intraspecific variability of $S$. schevyrewi without the extensive set of specimens provided to me through surveys supported through, and in many cases conducted by, USDA APHIS-PPQ and Forest Service. These surveys were also often conducted by colleagues in state agencies of agriculture and forestry, including many of my local colleagues of the Oregon Department of Agriculture.

Last, but certainly not least, my profound thanks to the Oregon Department of Agriculture for use of our wonderful extended depth of field imaging system and the exemplary talents of Steven A. Valley, who acquired the marvelous images used in this paper.

\section{References}

Bright DE (1975) The bark beetles of Canada and Alaska (Coleoptera: Scolytinae). The insects and arachnids of Canada, part 2, publication 1576. Canada Department of Agriculture, Ottawa, Ontario, 241 pp.

Bright DE, Skidmore RE (1997) A catalog of Scolytinae and Platypodidae (Coleoptera), Supplement 1 (1990-1994). National Research Council Research Press, Ottawa, Ontario, 368 pp. Bright DE, Skidmore RE (2003) A catalog of Scolytinae and Platypodidae (Coleoptera), Supplement 2 (1995-1999). National Research Council Research Press, Ottawa, Ontario, 523 pp. Canadian Food Inspection Agency (CFIA) (2002) Plant Pest Information, Tetropium fuscum, Brown Spruce Longhorn Beetle. http://www.inspection.gc.ca/english/ppc/science/pps/ datasheets/tetfuse.shtml. [accessed 15.VI.2006]

Furniss MM, Johnson JB (2002) Field guide to the bark beetles of Idaho and adjacent regions. University of Idaho, Moscow, Idaho, 125 pp.

Haack RA (2006) Exotic bark- and wood-boring Coleoptera in the United States: recent establishments and interceptions. Canadian Journal of Forest Research 36: 269-288. 
Hoebeke ER (1994) New records of immigrant bark beetles (Coleoptera: Scolytinae) in New York: Attraction of conifer-feeding species to ehtanol-baited trap logs. Entomological News 105: 267-275.

Hoebeke ER (1999) Japanese cedar longhorned beetle in the eastern United States. United States Department of Agriculture, Animal and Plant Health Inspection Service (APHIS) Pest Alert 81-35-004.

Hoebeke ER, Rabaglia RJ (2007) First reported occurrence of Xyleborinus alni (Coleoptera: Curculionidae: Scolytinae) in the eastern United States, with notes on its recognition and tree hosts. Proceedings of the Entomological Society of Washington 109: 240-248.

LaBonte JR, Mudge AD, Johnson KJR (2005) Nonindigenous woodboring Coleoptera (Cerambycidae, Curculionidae: Scolytinae) new to Oregon and Washington, 1999-2002: consequences of the intracontinental movement of raw wood products and solid wood packing materials. Proceedings of the Entomological Society of Washington 107: 554-564.

LaBonte JR, Rabaglia, RJ, Hoebeke, ER (2003) A screening aid for the identification of the banded elm bark beetle, Scolytus schevyrewi Semenov. http://ceris.purdue.edu/napis/pests/ barkb/index.html\#schevy [accessed 15.VI.2006]

Lee JC, Aguayo I, Aslin R, Durham G, Hamud SM, Moltzan BD, Munson AS, Negron JF, Peterson T, Ragenovich IR, Witcosky JJ, Seybold SJ (2009) Co-occurrence of the invasive banded and European elm bark beetles (Coleoptera: Scolytinae) in North America. Annals of the Entomological Society of America 102(3): 426-436.

Lee JC, Flint ML, and Seybold SJ (2008) Suitability of pines and other conifers as hosts for the invasive Mediterranean pine engraver, Orthotomicus erosus (Coleoptera: Scolytinae) in North America. Journal of Economic Entomology 101: 829-837.

Maier CT, Lemmon CR (2000) Discovery of the Small Japanese Cedar Longhorned Beetle, Callidiellum rufipenne (Motschulsky) (Coleoptera: Cerambycidae) in live arbovitae in Connecticut. Proceedings of the Entomological Society of Washington 102: 747-754.

McCullough DG, Roberts DL (2002) Emerald Ash Borer. USDA Forest Service Pest Alert NA-PR-07-02.

Michalski J (1973) Revision of the Palearctic species of the genus Scolytus Geoffroy (Coleoptera, Scolytinae). Polska Akademia Nauk Zaklad Zoologii Systematyczneji. Doswiadczalnej, Panstwowe Wydawnictwo Naukowe. Warsaw, Poland, 214pp.

Mudge A, LaBonte JR, Johnson KJ, LaGasa EC (2001) Exotic woodboring Coleoptera (Micromalthidae, Scolytinae) and Hymenoptera (Xiphydriidae) new to Oregon and Washington. Proceedings of the Entomological Society of Washington 103: 1011-1019.

National Agricultural Pest Information System (NAPIS). http://ceris.purdue.edu/napis/ [accessed 15.VI.2006]

Negron JF, Witcosky JJ, Cain RJ, LaBonte JR, Duerr II DA, McElwey SJ, Lee JC, Seybold SJ (2005) The banded elm bark beetle: a new threat to elms in North America. American Entomologist 51: 84-94.

Rabaglia R, Duerr D, Acciavatti R, Ragenovich I (2008) USDA Forest Service Early Detection and Rapid Response Project for non-native bark and ambrosia beetles: summary of the 2001-2005 pilot project. USDA-USFS, Forest Health Protection, 12 pp. 
Schiff NM, Valley SA, LaBonte JR, Smith DR (2006) Guide to the siricid woodwasps of North America. USDA Forest Service, Forest Health Technology Enterprise Team, Morgantown, West Virginia, 102 pp.

Solomon JD (1995) Guide to insect borers in North American broadleaf trees and shrubs. Agriculture Handbook 706. United States Deparment of Agriculture, Forest Service,. Washington, D.C., 735 pp.

Vandenberg NJ, Rabaglia RJ, Bright DE (2000) New records of two Xyleborus (Coleoptera: Scolytinae) in North America. Proceedings of the Entomological Society of Washington 102: 62-68.

Wood SL (1982) The bark and ambrosia beetles of North and Central America (Coleoptera: Scolytinae), a taxonomic monograph. Great Basin Naturalist 6: 1-1356.

Wood SL, Bright Jr DE (1992) A catalog of Scolytinae and Platypodidae (Coleoptera). Part 2: Taxonomic Index. Vol. A. Great Basin Naturalist Memoirs 13: 1-833. 